\title{
Analisis Krisis Penginjilan Di Kalangan Gereja Di Indonesia
}

\author{
Djone Georges Nicolas \\ STT Kairos Jakarta \\ djonealexandrenathanael@gmail.com
}

\begin{abstract}
Evangelizing which is commonly called "preaching the good news" is not only a belief that has been bestowed on every person who believes in Jesus Christ, but also an obligation that His church must carry out as one of the priority tasks. However, evangelism in fact ranks as the fourth leading cause of the growth in the number of congregations in the church in the last ten years with a figure of only $1.7 \%$. This study aims to analyze the causes of the crisis of evangelism among churches in Indonesia in an effort to maximize the implementation of the fulfillment of the Great Commission of Jesus Christ. The descriptive qualitative approach is the method used in the implementation of this research by analyzing and collecting data through book sources and digital articles, as well as journals and other documents related to the topic that is the subject of the study. As a result, the causes of the crisis of evangelism among churches in Indonesia are due to: First, some believers feel they are not called to be evangelists and so feel unable to evangelize. Second, some believers know that preaching the Good News is the responsibility of believers and the church, but are afraid of the threats that can be experienced related to carrying out the preaching of the gospel. In conclusion, evangelism is not an option that can be chosen, but the obligation of every believer based on love for God and neighbor. The crisis in the implementation of evangelism has proven to be hampering the growth of the church in Indonesia, because without the implementation of evangelism, it is difficult to see the Kingdom of God being enlarged on this earth.
\end{abstract}

Keywords: Crisis; Evangelism; Church; Indonesia

\begin{abstract}
Abstrak
Menginjili yang biasa disebut "memberitakan kabar baik" merupakan bukan sekedar kepercayaan yang telah dianugerahkan kepada setiap orang yang percaya kepada Yesus Kristus, tetapi juga suatu kewajiban yang harus dilaksanakan oleh gereja-Nya sebagai salah satu tugas yang prioritas. Namun, penginjilan pada kenyataannya menempatkan urutan keempat penyebab utama pertumbuhan jumlah jemaat di gereja dalam sepuluh tahun terakhir dengan angka sebatas 1,7\%. Penelitian ini mempunyai tujuan menganalisis penyebab krisis penginjilan di kalangan gereja di Indonesia dalam rangka usaha memaksimalkan pelaksanaan penuntasan Amanat Agung Yesus Kristus. Pendekatan kualitatif deskriptif menjadi metode penggunaan dalam pelaksanaan penelitian ini dengan menganalisis dan mengumpulkan data melalui sumber buku maupun artikel digital, serta jurnal dan dokumen lain yang berhubungan dengan topik yang menjadi pokok kajian. Hasilnya, penyebab krisis penginjilan di kalangan gereja di Indonesia adalah karena: Pertama, sebagian orang percaya merasa tidak terpanggil untuk menjadi penginjil sehingga merasa tidak mampu menginjili. Kedua, Sebagian orang percaya mengetahui bahwa pemberitaan Kabar Baik merupakan tanggung jawab orang percaya dan gereja, namun takut terhadap ancaman yang dapat dialami berkaitan dengan pelaksanaan pemberitaan Injil. Kesimpulan, penginjilan bukanlah sebuah opsi yang dapat dipilih, melainkan kewajiban setiap orang percaya yang dilandaskan pada kasih akan Tuhan dan sesama.
\end{abstract}


Krisis dalam pelaksanaan penginjilan terbukti menghambat pertumbuhan gereja di Indonesia, sebab tanpa pelaksanaan penginjilan, sulit melihat Kerajaan Allah diperbesar di bumi ini.

\section{Kata Kunci: Krisis; Penginjilan; Gereja; Indonesia}

\section{Pendahuluan}

Menginjili yang biasa disebut "memberitakan Kabar Baik" merupakan bukan sekedar kepercayaan yang telah dianugerahkan kepada setiap orang yang percaya kepada Yesus Kristus, tetapi juga suatu kewajiban yang harus dilaksanakan oleh gereja-Nya. Penginjilan menurut Kamus Besar Bahasa Indonesia (KBBI) diartikan sebagai proses maupun cara, serta perbuatan menginjil. Dengan kata lain penginjilan merupakan tindakan mewartakan kabar sukacita tentang Yesus Kristus dan karya-Nya yang besar bagi manusia. Meneguhkan hal pandangan tersebut, Hannas dan Rinawaty (2019) menyampaikan bahwa penginjilan dapat dimengerti sebagai suatu aktivitas yang bertujuan mengabarkan Injil secara pribadi, di mana Injil bermakna berita tentang Kristus yang mengalami kematian dan dikuburkan demi menebus semua manusia yang berdosa, serta bangkit menganugerahkan hidup kepada mereka hidup yang tidak fana. Penginjilan merupakan bagian dari misi gereja. Misi sendiri adalah luas, sebab istilah tersebut ditemukan juga di dalam dunia sekuler seperti istilah: misi diplomatis, misi politis, misi militer yang dapat dipahami sebagai pelimpahan tugas maupun tanggung jawab. Di kalangan gereja, misi menyangkut semua aktivitas gerejawi termasuk karya pewartaan dan penyebaran keyakinan atau iman Kristen.

Menurut Manurung (2020), misi dari kata missio dalam bahasa Latin yang maknai sebagai pengutusan. Maka, dalam teologi misi, misi dapat dimaknai sebagai rencana pengutusan Allah yang kekal untuk menghadirkan shalom baik kepada umat-Nya, maupun kepada dunia ini. Misi berpusat dan berasal dari Allah, di mana Allah mengutus umat Allah sebagai gereja dan alat-Nya untuk membawa atau menghadirkan Kerajaan-Nya yang memerdekakan dunia. Jadi, penginjilan merupakan salah satu tugas yang dibebankan kepada orang percaya dalam panggilan misi yang dari Allah. Dalam sepuluh tahun terakhir, penginjilan menempatkan posisi urut yang keempat penyebab utama pertumbuhan jumlah jemaat di gereja di Indonesia dengan angka hanya 1,7\%, di bawah perpindahan jemaat dari gereja yang lain sebesar $45,7 \%$, kelahiran anak dalam keluarga yang juga disebut pertumbuhan biologis sebesar 23,8\%, pernikahan jemaat dengan pasangan yang berkeyakinan agama yang berbeda sebesar $11,8 \%$, umat yang mengalih dari agama lain yang juga disebut konversi sebesar 6,7\%, dan perpindahan lokasi tempat tinggal sebesar 2,2\% menurut data survei Bilangan Research Center Handi dan Bambang (2020).

Menurut Kosma Manurung (2020), penginjilan sebagai misi gereja harus tetap fokus kepada mereka yang belum beriman kepada Kristus, dan itu dapat terlaksana jika gereja terlibat secara aktif dalam kegiatan sosial maupun budaya rakyat setempat seperti terbukti menopang pertumbuhan Gereja Sidang Jemaat Allah (GSJA) di Kalimantan Barat. Menurut Kalis Stevanus (2020), pemahaman akan dasar pelaksanaan penginjilan terlalu penting di kalangan Kristen, karena Injil merupakan berita yang dari Allah dan berhubungan dengan keselamatan orang berdosa, sehingga penginjilan bertujuan membawa mereka juga percaya kepadaNya. Maka, Laia (2019), panggilan gereja tidak lain adalah memberitakan Kabar Baik tersebut dengan tujuan menuai jiwa-jiwa menghasilkan sebagai jemaat. Sependapat, Charles Spurgeon (2019) menyatakan Injil sebagai Kabar Baik yang bisa menghasilkan berkat keselamatan maupun sukacita, serta damai sejahtera yang sepenuhnya atas mereka yang mendengar dan menerima isinya, dikarenakan di dalam terkandung informasi yang bermanfaat baginya apa bila diketahui. 
Penginjilan harus menjadi gaya hidup semua orang percaya. Maka, Suhendro (2019) menyatakan menginjili perlu menjadi sebuah gaya hidup di dalam kalangan kristen di mana menginjili dipahami sebagai tanggung jawab bersama tanpa dibatasi hanya pada status tertentu seperti pendeta maupun yang bergelar penginjil. Namun di lain sisi, Edwin (2021) dalam penelitian yang dilakukannya pada mahasiswa teologi tingkat sarjana dan pascasarjana Sekolah Tinggi Teologi di empat instansi yang berbeda, terdapat inkonsistensi dikarenakan 100\% responden sependapat bahwa pelaksanaan penginjilan pribadi sangatlah penting, namun 5\% saja yang melaksanakannya. Penulis searah dan sependapat dengan Suhendro bahwa seharusnya tindakan menginjili selazimnya menjadi gaya hidup semua orang percaya dikarenakan keberadaan orang percaya pada hakekat-nya merupakan surat Kristus yang terbuka bagi dunia ini sesuai 2 Korintus 3:3, sehingga sesuai data Edwin penulis berpendapat bahwa bukan sekedar terdapat inkonsistensi di kalangan Kristen, tetapi lebih jauh terdapat suatu krisis dalam pelaksanaan tugas penginjilan di kalangan gereja sehingga apa bila tidak segera ditemukan akar masalahnya, berpotensi akan semakin merugikan pelaksanaan misi yang Allah tangguhkan kepada orang percaya sebagai utusan-Nya.

Berdasarkan pemaparan yang telah ditampilkan di atas, dapat diperhatikan betapa penting dan bermanfaat pelaksanaan penginjilan oleh gereja demi penggenapan Amanat Agung Yesus Kristus bagi pembebasan manusia dari dosa yang mencengkeram mereka sesuai kehendak Allah untuk menjadikan segala suku bangsa murid Kristus. Dalam penelitian ini, penulis lebih memberi penekanan pada apa yang menjadi penyebab krisis penginjilan di kalangan gereja sehingga pelaksanaan penginjilan yang seharusnya maksimal dalam mendorong pertumbuhan gereja, justru kelihatan berjalan di tempat atau dengan kata lain tidak menunjukkan tajinya seperti terdapat pada gereja mula yang dipimpin para Rasul. Oleh karena itu, penelitian ini mempunyai tujuan menganalisis penyebab krisis penginjilan di kalangan gereja di Indonesia dalam rangka usaha memaksimalkan pelaksanaan misi Allah, atau penuntasan Amanat Agung Yesus Kristus.

\section{Metode}

Penelitian ini dilaksanakan dengan pendekatan kualitatif deskriptif sebagai metode penggunaan dengan menganalisis dan mengumpulkan data melalui sumber buku maupun artikel digital, serta jurnal dan dokumen lain yang berhubungan dengan topik yang menjadi pokok kajian. Metode ini digunakan untuk deskripsikan penyebab krisis penginjilan di kalangan gereja di Indonesia dalam pelaksanaan penuntasan Amanat Agung Yesus Kristus. Menurut Bodgan (Amir, 2020), penelitian kualitatif merupakan suatu prosedur penelitian yang memberi hasil data yang dengan tipe deskriptif semacam ucapan dan juga tulisan, serta perilaku oknum-oknum yang dilihat dalam suatu konteks dengan sudut kajian komprehensif dan juga holistik.

\section{Hasil dan Pembahasan}

Pemberitaan Injil menurut keempat Injil dan secara khusus dalam Matius 28:18-20 bersifat perintah, sehingga demikian menunjukkan betapa krusial pelaksanaannya. Kepentingannya semakin nyata oleh karena pemberitaan Injil bertujuan menjangkau semua orang di seluruh bangsa yang terdapat di bawah kolong langit. Yesus Kristus secara pribadi yang memberi perintah untuk pergi, yang berbicara bergerak dan bukan statis, aktif dan bukan pasif, beraksi dan bukan diam. Wijiati (2020) menyatakan bahwa dalam segala usaha yang dilaksanakan gereja dalam rangka mencapai multiplikasi sebagai ekspresi pelaksanaan misi seturut dengan Matius 28:19-20, pemberitaan Injil harus menjadi harga mati bagi gereja sebagai pelaksana Amanat Agung Tuhan Yesus. Hal ini diteguhkan oleh Injil Markus 16:15-16 (TB) ketika Yesus menyuruh murid-murid-Nya untuk pergi ke 
seluruh dunia dengan tugas memberitakan kepada segala makhluk Injil Kerajaan Allah, agar siapa pun yang menerimanya karena percaya dan mengikat perjanjian dengan Dia melalui baptisan beroleh keselamatan. Maka menurut Saptono (2019), gereja yang menunjukkan pertumbuhan terlibat dalam pelaksanaan penginjilan secara personal, umum dan juga secara institusional, sehingga terdapat usaha aktif dalam menginjili bukan saja dalam tingkat lokal tetapi juga secara regional dan juga internasional, dan bukan sekedar secara lokal.

Melalui wawancara dengan beberapa jemaat Gereja Bethel Indonesia (GBI) dan Gereja Sungai Yordan (GSY) yang terdapat di wilayah Taman Palem Lestari Cengkareng di Jakarta Barat, terdapat dua jawaban utama yang menjadi penyebab mereka tidak melaksanakan pemberitaan Injil, yakni: Pertama, merasa tidak terpanggil untuk menjadi penginjil karena tidak memiliki karunia dalam bidang tersebut, sehingga merasa tidak mampu menginjili. Dengan kata lain, tidak mengetahui bahwa tugas pemberitaan Injil ditangguhkan kepada setiap orang yang beriman kepada Tuhan di dalam Kristus Yesus. Kedua, mengetahui bahwa pemberitaan Kabar Baik merupakan tanggung jawab orang percaya dan gereja, namun takut terhadap ancaman yang dapat dialami berkaitan dengan pelaksanaan pemberitaan Injil seperti tuntutan hukum penistaan agama atau tuduhan kristenisasi, sehingga berpendapat bahwa Tuhanlah melalui Roh Kudus yang akan berkarya menjamah mereka oleh karena kemurahan dan kasih-Nya. Sebagian orang percaya merasa tidak terpanggil untuk menjadi penginjil, merasa tidak mampu menginjili.

Menurut Arifianto dan Purnama (2020) berpendapat bahwa setiap orang percaya dalam rangka pelaksanaan pemberitaan Injil perlu memperlengkapi diri secara pengetahuan kebenaran tentang Injil itu sendiri, namun perlu juga memiliki kehidupan yang bersesuaian dengan Kabar Baik yang diberitakan. Kalis Stevanus (2017) menerangkan bahwa pemberitaan Injil berhubungan erat dengan panggilan untuk bertobat, sehingga terdapat unsur ganda dalam memperoleh keselamatan, yakni kasih karunia dan iman yang walaupun berbeda saling berhubungan, sebab iman merupakan tindakan menerima anugerah yang diberikan Allah, karena anugerah memerlukan respons manusia yang terikat oleh kuasa dosa. Surat Roma menyatakan bahwa keselamatan tersedia bagi mereka yang menyerukan nama Tuhan, namun apa bila mereka tidak mempunyai kepercayaan kepada Tuhan bagaimana mereka dapat menyerukan nama-Nya? Sulit beriman kepada Tuhan apa bila tidak mendengar berita tentang pribadi-Nya, dan bahkan mustahil mereka mendengar berita tentang Dia apa bila tidak ada melaksanakan pemberitaan Injil (Roma 10:13-14). Hal tersebut menunjukkan sebuah proses yang berkesinambungan menuju pembenaran yang dari Allah melalui iman, namun iman itu timbul oleh karena pendengaran akan berita Kabar Baik (Roma 10:17), sehingga pemberitaan tersebut menjadi suatu peristiwa yang tidak bisa ditiadakan, oleh karena pendengaran sangat dibutuhkan orang-orang yang belum percaya kepada Kristus agar mereka dapat percaya kepada-Nya dan dipulihkan.

Badai dkk (2020) berpendapat bahwa keselamatan merupakan sesuatu yang terlalu penting sehingga penginjilan harus dikobarkan, sehingga anak-anak pun dapat memiliki pemahaman yang pasti dan jelas melalui bimbingan tentang makna Injil, yang memperkuat kemampuan intelektual mereka, sehingga pemahaman yang baik tersebut dapat mendorong mereka menjadi pelaksana pemberitaan Injil bagi sesama mereka. Maka Amsal 23:23 (TB) menyarankan untuk membeli kebenaran, hikmat, pendidikan serta pengertian serta hindari menjualnya, sebab begitu penting dan mahalnya pengetahuan akan Allah, akan rencana-Nya, akan karya dan juga apa yang menjadi kehendak-Nya bagi kita dan melalui kita bagi dunia ini. Persoalannya adalah bahwa yang memberitakan Kabar Baik tersebut seharusnya semua orang percaya yang telah diutus oleh Tuhan, tetapi tidaklah semua orang percaya mengindahkan perintah-Nya. 
Dalam Kitab Hosea 4:6, firman Tuhan mengingatkan bahwa alasan umat Allah mengalami kebinasaan adalah semata-mata karena kurang-nya pengetahuan akan Allah. Demikian juga, pengetahuan akan kehendak Allah yang hendak semua orang diselamatkan sehingga tidak terdapat orang yang binasa menjadi suatu keharusan bagi setiap orang percaya, sebab melalui pembaharuan akal budi, orang percaya justru seharusnya mengetahui kehendak Allah yang baik, berkenan dan sempurna seperti tertulis dalam Roma 12:2. Maka Afrianto dkk. (2020) berpandangan bahwa terdapat kesalahan dalam pemahaman tentang penginjilan sehingga gereja sebagai saksi Kristus di dunia ini juga tidak melaksanakan pemberitaan Injil secara benar. Oleh karena itu, Sampurna (2020) menyampaikan bahwa Injil mempunyai posisi yang sangat strategis di kalangan Kristen sebab pemberitaan Injil merupakan karya maupun rencana Allah sehingga wajib terus karena Allah bekerja sama dengan manusia demi pencapaian tujuan Ilahi yang tidak lain adalah keselamatan bagi semua manusia. Lumantow dan Agung (2021) sependapat dengan menegaskan bahwa oleh karena fenomena di masa ini begitu banyak dan beragam, penginjilan menjadi kebutuhan mendesak dalam rangka usaha mengembalikan manusia pada kehormatannya melalui pengalaman akan Tuhan.

Kisah Para Rasul 1:8 menegaskan keinginan hati Yesus yang disampaikan langsung kepada murid-murid-Nya, agar mereka menjadi saksi-saksi-Nya di mana pun mereka berada, termasuk sampai ke ujung bumi melalui pemberitaan Kabar Sukacita: yakni Injil. Handi Irawan dkk. (2018) mengutip Win Arn yang adalah seorang peneliti di Amerika, mengutarakan bahwa pemberitaan Kabar Baik yang dilaksanakan melalui persahabatan adalah sangat efektif, didasari dari penelitiannya terhadap 17.000 narasumber di mana $79 \%$ mengakui mengenal Kristus oleh kontribusi teman yang memberitakan tentang Dia kepada mereka. Maka diperlukan juga pembekalan secara internal terhadap jemaat berbentuk pengajaran tentang penginjilan dan strategi-strategi dalam menginjil sebagai bagian mempersiapkan mereka dengan pengetahuan yang cukup untuk pelaksanaan pemberitaan Injil di lingkungan di mana mereka diizinkan berada oleh anugerah Tuhan. Tanpa pengetahuan akan kehendak Allah dan akan pesan yang jelas tentang tugas yang telah dipercayakan kepada gereja sebagai umat Allah, mustahil pelaksanaan Amanat Agung atau misi Allah dapat dipraktikkan dengan tepat, oleh karena pengetahuan dan pemahaman yang benar merupakan fondasi yang kuat dan dasar awal dalam pelaksanaan pemberitaan Injil. Sebagian orang percaya mengetahui bahwa pemberitaan Kabar Baik merupakan tanggung jawab orang percaya dan gereja, namun takut terhadap ancaman yang dialami berkaitan dengan pelaksanaan pemberitaan Injil.

Penginjilan menurut Han dan Pandie (2020) merupakan hakekat Gereja, oleh karena gereja identik dengan penginjilan. Walaupun mengetahui bahwa pemberitaan Kabar Baik merupakan tanggung jawab orang percaya dan gereja, namun sebagian orang percaya merasa takut menghadapi ancaman yang berhubungan dengan pelaksanaan pemberitaan Injil, seperti tuntutan hukum penistaan agama atau tuduhan kristenisasi, serta ancaman dipenjarakan, sehingga berpendapat bahwa Tuhanlah melalui Roh Kudus yang akan berkarya menjamah mereka oleh karena kemurahan dan kasih-Nya. Apa bila merujuk kembalikan pada Amanat Agung yang terdapat di dalam Matius 28:18-20 dengan perintah tegas untuk pergi menghasilkan murid melalui penginjilan, pembaptisan, pemuridan dan pengajaran, tentu melemparkan tanggung jawab tersebut kepada menunjukkan terdapat masalah atau krisis kasih terhadap Tuhan. Sebab, Yohanes 14:15 menegaskan bahwa kasih terhadap Kristus ditunjukkan melalui ketaatan akan perintah-perintah yang Dia berikan, terlebih dasar kedatangan Kristus di dunia ini, karya dan pengorbanan-Nya selalu adalah karena kasih, sebab Allah sendiri adalah Kasih sehingga siapapun yang tidak menunjukkan kasih tidak punya pengenalan akan Allah sesuai 1 Yohanes 4:8 (TB). 
Di lain sisi, kasih kepada Allah terwujud dan diimplementasikan di dalam kasih yang ditujukan kepada sesama. Searah, Suhendro (2019) menyampaikan bahwa gaya hidup pemberitaan Injil dikehendaki Tuhan dalam gereja, yaitu gaya hidup penuh kasih terhadap sesama yang perlu mendengar berita Injil tentang kemuliaan Allah. Kedua, ancaman penjara karena tuduhan penistaan agama maupun kristenisasi tidak dapat diterima dikarenakan memberitakan Injil merupakan keharusan yang kalau tidak dilakukan seharusnya merasa malu dan berdosa terhadap Tuhan dan sesama, seperti yang dikatakan Paulus dalam 1 Korintus 9:16 (TB) dengan menekankan bahwa pemberitaan Injil tidak bertujuan memegahkan diri, melainkan keharusan sehingga haram dan celaka apa bila ia tidak memaksakannya. Paulus yang berkata dalam Filipi 1:21 bahwa hidup adalah Kristus dan risiko kematian karena Kristus merupakan keuntungan. Jadi ancamanancaman yang ditakuti di era ini tidak sebanding dengan ancaman yang telah dialami para Rasul, yaitu nyawa mereka demi tetap pemberitaan Kabar Baik dilaksanakan demi jiwajiwa yang butuh diselamatkan. Walaupun pemberitaan Injil harus diakui perlu dilakukan dengan sopan santun dan hikmat, tanpa niat mencederai keyakinan agama yang lain. Suwito dkk. (2021) menyampaikan bahwa terdapat beberapa pendorong orang memberitakan kabar baik, di mana salah satunya adalah karena hatinya dipenuhi oleh kasih Allah sehingga orang tersebut juga bersedia mengasihi mereka yang belum percaya.

Salah satu bagian berita Injil adalah bahwa Allah karena kasih-Nya telah rela menjadi manusia, tinggal di tengah dan bersama manusia berdosa, merasakan apa yang dirasakan manusia dan menebus manusia berdosa untuk dikembalikan pada kodratnya yang sesungguhnya. Kelahiran Yesus sebagai manusia yang dirayakan sebagai peringatan yang disebut Natal, di dua tahun terakhir berbeda dengan yang sebelumnya karena kondisi dan dampak pandemi Covid-19, di mana kecemasan dan depresi telah merajalela di tengah masyarakat, termasuk di dalam gereja. Persekutuan Gereja-gereja di Indonesia (2020) dalam situs resminya melalui survei yang telah dilakukannya mengungkapkan bahwa terdapat $73,1 \%$ orang yang merasakan tanda depresi yang ringan, 21,9\% dengan tanda depresi sedang, 3,5\% dengan tanda depresi yang cukup serius, dan 1,5\% dengan tanda depresi yang serius (Potensi bunuh diri). Demikian juga Perhimpunan Dokter Spesialis Kedokteran Jiwa di Indonesia menyatakan bulan Juli 2020 bahwa terdapat 1522 orang mengalami gangguan kesehatan mental dan $63 \%$ di antaranya terserang kecemasan $(65 \%)$, depresi (62\%) dan juga trauma (75\%). 1 di antara 5 orang mempunyai pikiran untuk lebih baik tidak hidup lagi alias mati dengan keinginan dengan cara apa pun mencelakakan diri sendiri (44\%) sesuai data di situs resminya "PDSKJI|PDSKJI.org" http://pdskji.org/home.

Kondisi yang demikian adalah fakta yang dialami oleh dunia ini secara lahiriah yang belum sebanding dengan dampak dosa, sehingga gereja Tuhan yang merupakan terang dan garam di tengah dunia ini, seharusnya karena terdorong oleh kasih kepada Allah dan sesama bersinar di tengah kegelapan dengan memberitakan Kabar Sukacita karena dua alasan apa bila dipandang dari Yohanes 3:16: Pertama, karena kesadaran bahwa kasih Allah adalah ditujukan kepada semua orang tanpa terkecuali, sebab dasar Allah mengaruniakan Yesus yang merupakan Anak Tunggal-Nya adalah karena kasih-Nya pada dunia ini dan bukan sebatas untuk umat beragama Kristen secara khusus. Orang-orang percaya yang sudah mengalami kasih Allah karena anugerah-Nya sehingga dipanggil dan ditetapkan umenjadi "Surat Kristus yang terbuka" hendaklah mengasihi sesama yang belum beriman kepada Kristus bukan seledar dengan perkataan yang manis lidah, namun dengan perbuatan nyata yang menggambarkan kebenaran, sehingga dengan demikian kasih Allah dapat terlihat (1 Yohanes 3:17-18 (TB)). Sebab seperti Yesus, apa pun juga yang dilakukan oleh pengikut-Nya digerakkan oleh belas kasihan terhadap jiwa-jiwa. Kedua, dorongan memberitakan Kabar baik seharusnya dilaksanakan karena kasih yang 
menyadarkan bahwa dunia ini membutuhkan kasih Kristus untuk keluar dari kegelapan dan memiliki pengharapan. Sebab, alasan berikut adalah karena dunia atau orang yang belum percaya sedang terancam mengalami kebinasaan yang diartikan sebagai kehancuran secara total, tersesat, gagal, mengalami kematian dan kesengsaraan. Maka, gereja wajib mengasihi dunia sama seperti Allah mengasihi dunia, dan gereja harus berhenti menjadi hakim atas dunia, tetapi memberitakanlah Kabar Baik bagi dunia agar mereka alami apa yang sudah orang percaya alami (Kasih Karunia Allah). Hal tersebut dapat diwujudkan dalam konteks terkini melalui sarana pelayanan sosial sebagai contoh yang nyata. Han dan Pandie (2020) sependapat berpandangan bahwa model penginjilan melalui pelayanan sosial di tengah masyarakat melalui berbagai sarana seperti bantuan medis, pendidikan dan tipe yang lain dapat dilaksanakan, dan itu tidak dapat disebut atau dipandang sebagai suatu upaya "kristenisasi", melainkan sebagai implementasi dan bukti nyata dari kasih Kristus melalui gereja maupun orang percaya secara keseluruhan.

Dengan memberitakan Kabar Baik, gereja bersinar dan dengan demikian menjadi berkat bagi dunia yang dipenuhi kegelapan. Tetapi sebaliknya dengan tidak melaksanakan tanggung jawab kesaksian tentang karya Kristus, sesungguhnya krisis kasih sudah merasuki gereja dan umat Allah, sebab Yesus telah hadir menjadi terang bagi dunia, dan gereja hari ini hadir sebagai Tubuh Kristus untuk melanjutkan karya Kristus demi keselamatan dunia ini. Seperti dikatakan oleh Hannas dan Rinawaty (2019) bahwa semangat orang Kristen hendaklah dalam pengabaran Injil tetap berkobar-kobar dan dengan penuh antusiasme demi tujuan kemenangan jiwa-jiwa bagi kemuliaan Kristus dalam karya Roh Kudus. Sebab melalui Roh Kudus, Allah tidak sekedar menganugerahkan Penolong atau Parakletos bagi orang percaya dalam hal kuasa dan kemampuan supranatural, tetapi melalui Roh Kudus yang sama, Allah telah menanam kasih-Nya yang menampukkan setiap orang dapat mengasihi Allah dan sesama. Salah satu bukti kasih terhadap sesama adalah kerinduan untuk melihat mereka terbebas dari kegelapan dunia dan dosa, dan menikmati keselamatan yang sudah tersedia oleh anugerah Allah di dalam Kristus Yesus.

\section{Kesimpulan}

Penginjilan bukanlah sebuah opsi yang dapat dipilih, melainkan kewajiban setiap orang percaya yang dilandaskan pada kasih akan Tuhan dan sesama. Krisis dalam pelaksanaan penginjilan menghambat pertumbuhan gereja di Indonesia, sebab tanpa pelaksanaan penginjilan, sulit melihat Kerajaan Allah diperbesar di bumi ini. Dengan fakta bahwa sebagian orang percaya merasa tidak terpanggil untuk menjadi penginjil sehingga merasa tidak mampu menginjili, serta sebagian mengetahui bahwa pemberitaan Kabar Baik merupakan tanggung jawab orang percaya dan gereja, namun takut terhadap ancaman yang dapat dialami berkaitan dengan pelaksanaan pemberitaan Injil, gereja perlu mengevaluasi pelayanan yang sudah dipraktikkan selama ini, khususnya dalam hal pengajaran dan usaha lain dalam rangka menyadarkan dan mendorong jemaat sebagai Tubuh Kristus, untuk mengambil bagian dalam pelaksanaan penginjilan seturut dengan kehendak Allah. Sebab, pengetahuan akan kebenaran firman Allah yang memerdekakan dan kasih akan Allah dan sesama harus menjadi perhatian khusus di kalangan gereja, agar menginjili sungguh-sungguh dapat menjadi gaya hidup setiap umat Allah sebagai bukti kasih terhadap Allah dikarenakan memiliki kerinduan untuk melihat mereka yang belum percaya terbebas dari kegelapan dunia dan dosa, dan dengan demikian, menikmati keselamatan yang sudah tersedia oleh anugerah Allah di dalam Kristus Yesus. 


\section{Daftar Pustaka}

Amir, H. (2020). Metode Penelitian dan Perkembangan. Journal of Undergraduate, Sosial Science and Technology, 3-9.

Arifianto, Y. A., \& Purnama, F. (2020). Misiologi Dalam Kisah Para Rasul 13: 47 Sebagai Motivasi Penginjilan Masa Kini. KHARISMA: Jurnal Ilmiah Teologi, 1(2), 117134.

Arifianto, Y. A., Triposa, R., \& Lembongan, P. K. (2020). Bible Study of Mission and Discipleship in the Great Commission and Its Implications for Today's Christian Life. DIEGESIS Jurnal Teologi, 5(25-42).

Badai, K., Djeremod, K., \& Keriapy, F. (2020). Penginjilan Sebagai Upaya Meneguhkan Keyakinan Keselamatan Anak. HARVESTER: Jurnal Teologi Dan Kepemimpinan Kristen, 5(2), 120-134.

Budijanto, B. (2018). Dinamika spiritualitas generasi muda Kristen Indonesia. Yayasan Bilangan Research Center.

Gandaputra, E. (2021). Memikirkan Ulang Aplikasi Penginjilan Pribadi Pada Masa New Normal. SAINT PAUL'S REVIEW, 1(1), 29-45.

Hannas, H., \& Rinawaty, R. (2019). Menerapkan Model Penginjilan pada Masa Kini. KURIOS (Jurnal Teologi dan Pendidikan Agama Kristen), 5(2), 175-189.

Irawan, H., \& Budijanto, B. (2020). Kunci Pertumbuhan Gereja Di Indonesia: Menyingkap Faktor Pendorong Pertumbuhan Gereja Berdasarkan Temuan Survey Nasional BRC. Jakarta: Yayasan Bilangan Research Center.

Laia, K. H. (2019). Pertumbuhan Gereja Dan Penginjilan Di Kepulauan Nias. FIDEI: Jurnal Teologi Sistematika dan Praktika, 2(2), 286-302.

Lima, J. S. (2020). Injil Sebagai Kabar Tentang Kembalinya Kemuliaan Tuhan Ke Dalam Segenap Ciptaan. Evangelikal: Jurnal Teologi Injili dan Pembinaan Warga Jemaat, 4(1), 1-13.

Lumantow, A. I. S., \& Agung, W. (2021). Orang Kristen dalam Sinergi Penginjilan Digital di Era Disrupsi. Sabda: Jurnal Teologi Kristen, 2(2), 99-113.

Manurung, K. (2020). Efektivitas Misi Penginjilan Dalam Meningkatkan Pertumbuhan Gereja. DUNAMIS: Jurnal Teologi dan Pendidikan Kristiani, 4(2), 225-233.

Pandie, D. A., \& Han, L. K. (2020). Urgensi dan Model Penginjilan di Masa Pandemi Covid-19. LOGIA: Jurnal Teologi Pentakosta, 2(1), 79-96.

Persekutuan Gereja-gereja di Indonesia (2020). Protet Wajah Gereja di Masa Pandemi Covid-19, diambil dari https://pgi.or.id/potret-wajah-gereja-di-masa-pandemicovid-19/

Saptono, Y. J. (2019). Pentingnya Penginjilan Dalam Pertumbuhan Gereja. DIEGESIS. Jurnal Teologi Kharismatika, 2(1), 12-24.

Spurgeon, C. H. (2019). Strategi Jitu Untuk Menjadi Pemenang Jiwa. Yogyakarta: Andi.

Stevanus, K. (2020). Karya Kristus Sebagai Dasar Penginjilan Di Dunia Non-Kristen. Fidei: Jurnal Teologi Sistematika dan Praktika, 3(1), 1-19.

Stevanus, K. (2017). Jalan Masuk Kerajaan Surga. Yogyakarta: Andi Offset

Suwito, T. P., Hermanto, Y. P., \& Tanama, Y. J. (2021). Penderitaan Dalam Konteks Penginjilan. Phronesis: Jurnal Teologi dan Misi, 4(1), 88-99.

Stephanus, D. S. P. (2019). Mengajarkan Penginjilan Sebagai Gaya Hidup Orang Percaya. REDOMINATE: Jurnal Teologi dan Pendidikan Kristiani, 1(1), 12-22.

Wijiati, M. (2020). Strategi Mengomunikasikan Injil Kepada Generasi Mileneal. Regula Fidei: Jurnal Pendidikan Agama Kristen, 5(2), 107-117. 